Apidologie, 1978, 9 (3), 167-174.

\title{
BIOLOGY OF HONEYBEE (APIS MELLIFERA L.) SPERMATOZOA 1. Effect of different diluents on motility and survival
}

\author{
L. R. VERMA* \\ Institut für Bienenkunde der Universität, \\ Frankfurt am Main, Oberursel, W. Germany.
}

\section{SUMMARY}

Honeybee semen was stored in different diluents at $14^{\circ} \mathrm{C}$ for 9 months. Fine disposable sterile capillary tubes of $0.1 \mathrm{~cm}$ diameter were used for semen storage. Sperm motility was assessed at regular intervals and queens were inseminated with freshly diluted and 60-90 days old semen samples. Tris buffer diluent ( $\mathrm{pH}: 7.19)$ containing concentration of $\mathrm{K}^{+}$and $\mathrm{Na}+$ as found in the spermatheca of the queen bee acted as a reversible inhibitor of sperm motility, even after 9 months of storage. This support our previous hypothesis af an ionic basis for the control of sperm motility and longevity.

The significance of various other diluents used for the preservation of semen of other domestic animals, with regard to in vitro survival of honeybee spermatozoa is discussed. Spermatozoa survived longer in tris buffer diluent at $\mathrm{pH}: 7.19$ than at $\mathrm{pH}: 8.4$.

Tris buffer diluent with cations and Varhom diluent II with catalase can possibly be used for increasing the volume of the freshly ejaculated semen, particularly when single drone inseminations are required for genetic studies. However, when the queens were inseminated with 60-90 days old semen samples, less than half million spermatozoa reached spermatheca. The development of a diluent for the prolonged storage of honeybee semen seems much more complicated than for the other domestic animals, because in the former ease millions of spermatozoa should remain viable in the spermatheca for 3 or more years.

\section{INTRODUCTION}

Since the discovery of instrumental insemination technique, many efforts have been made for developing a suitable diluent for the in vitro storage of honeybee semen (JAYCOX, 1960; LENSKY and Schindler, 1967; PoOle and TABER, 1969; 1970; TABer and Blum, 1960; Camargo, 1975 and Melnichenko and Vavilov, 1975). The in vitro storage of undiluted semen is possible for about 2 months (RUTTNER, 1975), although suitable diluents are not available. VERMA (1973)

Present address: Department of Bio-Sciences, H. P. University Simla, 171005, iNDIA 
reported that honeybee spermatozoa could be inactivated reversibly with an artificial tris (hydroxymethyl) aminomethane (tris) buffer ( $\mathrm{pH}: 7.19$ ), containing concentration of $\mathrm{Na}^{+}$and $\mathrm{K}^{+}$similar to those found in the queen bee spermatheca. He further suggested that hypertonic environment of the queen bee spermatheca due to high concentration of these cations, may be responsible for longevity of spermatozoa in a non-motile state. GESSNER and GesSNER (1976) also found concentration of $\mathrm{K}^{+}$ about 8 times higher and concentration of $\mathrm{H}^{+}$approximately 200 times lower in the spermathecal fluid than in the queen bee haemolymph. Spermathecal epithelium generated an electrical potential difference of $21 \mathrm{mV}$, lumen positive, suggesting that secretion of $\mathrm{K}^{+}$and other ions is an active energy dependent process.

The present investigation was carried out to study the effect of these cations on sperm survival under long term storage in vitro. The effect of other diluents used for the preservation of the semen of higher animals was also tested with regard to the long term in vitro survival of honeybee spermatozoa.

\section{MATERIALS AND METHODS}

Semen was collected from sexually mature drones using the method of RutrNer (1975). Fine disposable capillary tubes with a diameter of $0.1 \mathrm{~cm}$ were used for the storage of semen. The capillary tubes were attached to the insemination syringe by means of a small plastic tube and thus semen was drawn directly in to a storage tube. Following pattern was used while filling semen and diluent in the capillary tubes : $1 \mu$ l diluent- $1 \mu$ l semen- $1 \mu$ l diluent-1 $\mu$ l semen. About 20 to $30 \mu l$ of semen and diluent was placed in each tube and tube was cut about $3 \mathrm{~cm}$ above the level of semen. After filling the semen, the capillary tubes were sealed with small rubber cappings, which fit in tightly and can be removed easily without any chance of contaminating the semen.

The composition of diluents used in the present experiments were as follow.

A. Tris buffer diluent (VERMA, 1973).

Tris buffer $(\mathrm{pH}: 7.19)$

Sodium chloride

$100 \mathrm{ml}$

Potassium chloride

$0.065 \mathrm{~g}$

$0.060 \mathrm{~g}$

B. Tris buffer diluent (VERMA, 1973).

Tris buffer $(\mathrm{pH}: 8,4) \quad 100 \mathrm{ml}$

Sodium chloride $\quad 0.065 \mathrm{~g}$

Potassium chloride $\quad 0.060 \mathrm{~g}$

C. Tris buffer diluent (VERMA, 1973), with catalase.

Tris buffer (pH : 7.19) $\quad 100 \mathrm{ml}$

Sodium chloride $\quad 0.065 \mathrm{~g}$

Potassium chloride $\quad 0.060 \mathrm{~g}$

Dextrose $\quad 0.010 \mathrm{~g}$

Catalase (Behringwerke) $20 \% \quad 0.20 \mathrm{~g}$

D. Tris buffer diluent (VERMA, 1973) with amino acids.

Tris buffer (pH : 7.19) $\quad 100 \mathrm{ml}$

Sodium chloride $\quad 0.065 \mathrm{~g}$

Potassium chloride $\quad 0.060 \mathrm{~g}$

Lysine $\quad 0.010 \mathrm{~g}$

Arginine $\quad 0.010 \mathrm{~g}$ 
E. Tris buffer diluent $(p H: 7,19)$.

Sol. I Tris (hydroxymethyl)

$\begin{array}{lll}\text { amino methane } & 2.43 \mathrm{~g} \\ \text { Distilled water } & 100 \mathrm{ml}\end{array}$

Sol. II $\mathrm{Hcl} 0.1 \mathrm{~N}$

Sol. I

$25 \mathrm{ml}$

Sol. II

$45 \mathrm{ml}$

Distilled water $\quad 30 \quad \mathrm{ml}$

F. Tris deep freezing diluent for bull sperm (PAUFLER, 1974).

Tris (hydroxymethyl) amino-methane $3 \mathrm{~g}$

Fructose $\quad 1.25 \mathrm{~g}$

Citric acid $\quad 1.75 \mathrm{~g}$

Distilled water $\quad 100 \mathrm{ml}$

G. Varhom diluent II for boar sperm (PAUFLER, 1974).

Tri-Sodium citrate-2-hydrate $\quad 2.43 \mathrm{~g}$

$\mathrm{D}(+)$-Glucose-Monohydrate $\quad 0.3 \mathrm{~g}$

Sodium hydrogen carbonate $\quad 0.21 \mathrm{~g}$

Sulfanilamide $0.3 \mathrm{~g}$

Potassium chloride $\quad 0.04 \mathrm{~g}$

Distilled water $\quad 100 \mathrm{mI}$

H. Varhom diluent II with catalase

Varhom diluent II $\quad 100 \mathrm{ml}$

Catalase (Behringwerke $20 \%) \quad 0.20 \mathrm{ml}$

I. Glycine buffer $p H: 8,85$ (RUTTNER, 1975).

J. Coconut water (CAMARGO, 1975).

To all these diluents, streptomycin sulfate and penicillin were added as antibiotics. All the solutions were filtered through Sartorius membrane filters in order to sterilize them. All the glassware used was sterilized in an oven at $150^{\circ} \mathrm{C}$ for one hour.

All the capillary tubes containing the diluted semen were kept at $14^{\circ} \mathrm{C}$ in a refrigerator.

For observation of motility, the diluted semen from the capillary tube was mounted on a depression or culture slide vith a cover slip and sealed with vaseline. This prevented the drying of semen and permitted prolonged observation of a single sample. The motility of the sperm was classified into 4 grades ( 1 = weak, 4 = strong).

Motility factor was calculated according to the formula given below.

$\mathrm{MF}=\sum_{\mathrm{i}=1}^{\mathrm{i}=14} \frac{\mathrm{Si} \cdot \mathrm{Pi}}{100}$

$\mathrm{Si}=$ Motility at stage $\mathrm{i}$.

$\mathrm{Pi}=$ Percentage of motile spermatozoa at stage $\mathrm{i}$.

Queens were instrumentally inseminated with the stored semen. After insemination, queens were returned to the hive, kept there for 48 hours and then dissected in a physiological saline for counting the number of spermatozoa.

\section{RESULTS}

The effect of different diluents used in the present experiments on the motility of honeybee spermatozoa are shown in Table 1

Sperm cells became immediately non-motile after mixing the semen with diluents A to D. However, in diluents $\mathrm{E}$ to $\mathrm{J}$, they became inactive after remaining motile for 
TABL. 1. - Effect of different diluents on sperm motility

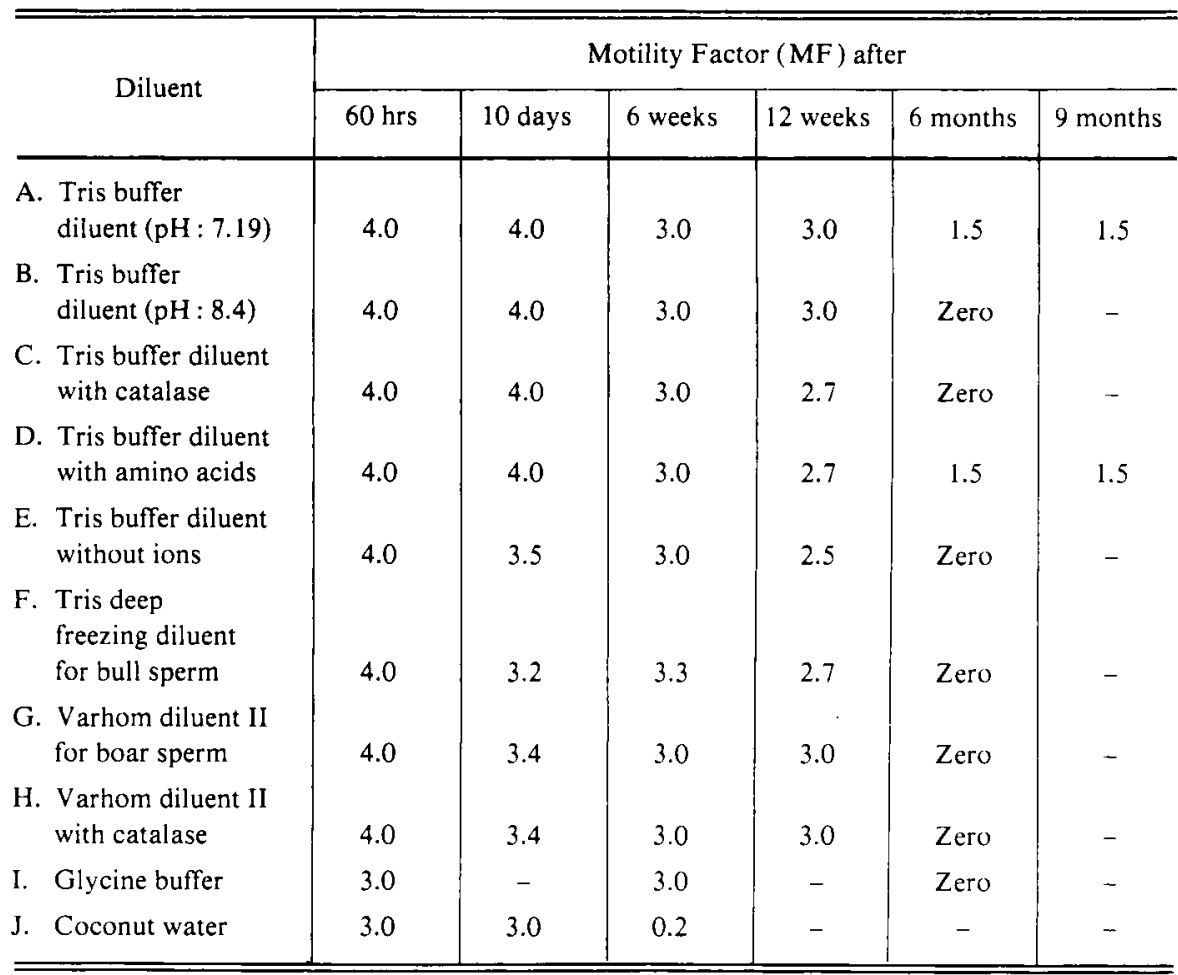

several hours. Tris deep freezing diluent for bull sperm (Diluent F) acted as a strong stimulant for honeybee spermatozoa motility and was used in the present experiments for distinguishing non-motile sperm from dead ones.

Even after 9 months of storage at $14^{\circ} \mathrm{C}$ spermatozoa mixed with diluents $\mathrm{A}$ and $\mathrm{D}$ could be reactivated. In other diluents about $60 \%$ spermatozoa were found motile after 6 to 12 weeks of storage. Comparison of the motility results of sperm cells in diluents $\mathrm{A}$ and $\mathrm{B}$, possibly indicate that $\mathrm{pH}: 7.19$ is more preferable than $\mathrm{pH}: 8.4 \mathrm{du}-$ ring long term storage.

Results with instrumental insemination show that when queens were inseminated immediately after mixing the fresh semen with the diluent $\mathrm{A}$, the same number of spermatozoa reached spermatheca as with undiluted semen or control. However, there was a decrease in the number of spermatozoa reaching spermatheca with the period of storage. For example, when queens were inseminated with 60 to 90 days old semen mixed with diluents A, D, F, G and H, only $30.000 ; 25.000 ; 55.000 ; 54.000$ and 325.000 spermatozoa reached spermatheca respectively. Addition of catalase in diluent $\mathrm{H}$ enhanced the number of sperm cells reaching spermatheca. Sperm cells dissected out of spermatheca showed spiral pattern of sperm motility. 


\section{DISCUSSION}

The present results support the hypothesis of VER AA (1973) that concentration of $\mathrm{Na}^{+}$and $\mathrm{K}^{+}$as present in the honeybee queen spermatheca is one of the important factor for the reversible suppression of sperm motility and longevity both in vivo and in vitro. The effect of cations on sperm motility and metabolism in other animals have been reviewed by SALISBURY and LODGE (1962) and NeLSON (1967). $\mathrm{Na}^{+}$is thought to play an inert role whereas $\mathrm{K}^{+}$appears to play an essential role in sperm metabolism and motility. Salisbury and Graves (1963) concluded that high $\mathrm{K}^{+}$content in the diluent for bull spermatozoa inhibited sperm motility by decreasing fructose uptake and thereby inhibiting ATP synthesis.

Spermatozoa survived longer in tris buffer diluent at $p \mathrm{H}: 7.19$ than at $p H:$ 8.4. CAMARGo (1975) also reported that coconut water with $p \mathrm{H}: 7.0$ acted as a good diluent for the storage of honeybee semen than at any other $p \mathrm{H}$. Amino acids analysis by NovaK et al. (1960) showed that arginine and lysine content of honeybee spermatozoa and seminal plasma was quite high. Addition of these amino acids to the diluents used in the present study prolonged the period of sperm motility.

In the present experiments, addition of catalase has beneficial effect on motility and more number of spermatozoa reached spermatheca. High activity of catalase has been reported in sea-urchin spermatozoa by RoTHSCHILD (1948). This enzyme decomposes hydrogen-peroxide which is produced by oxidative deamination of amino acids by the mammalian spermatozoa and accumulation of hydrogen-peroxide in the semen is considered toxic because it inhibit sperm fructolysis (Tosic and WALTON, 1950).

Based on motility and insemination results, we recommend Tris-buffer diluent A and Varhom diluent II with catalase as basic component for the dilution of freshly ejaculated semen. These diluents can possibly be used for increasing the volume of semen, particularly, when insemination with single drone is required for genetic studies.

Although, there was no significant decrease in sperm motility after 12 weeks of storage of semen in most of these diluents used in the present study, but less than half million spermatozoa reached spermatheca when queens were inseminated with these stored semen samples. This confirm the general view that sperm motility should not be regarded as a sole biological index of viability, although, it may be essential for fertilization.

The development of a diluent for the storage of honeybee spermatozoa is further complicated by the fact that millions of spermatozoa should reach spermatheca and retain their fertilizing ability for many years, because the queen honeybee mates only once in life time and continue to lay fertilized eggs for 3 or more years. So this situation is not comparable with the artificial insemination in higher mammals, where out of billions of sperm injected, only a few thousands reach the site of fertilization soon after insemination and only one single sperm cell is responsible for the fertilization of the ovum and production of a male or female offspring. 
An ideal diluent for prolonged in vitro storage of honeybee semen still remains a goal for future investigation and more basic information on the mechanisms of sperm transport, nutrition and metabolism is needed.

Received in May 1978

\section{ACKNOWLEDGEMENTS}

The author wishes to thank Prof. Dr F. RUTTNER for providing the working space in his laboratory and for critically reading the manuscript. Prof. RuttNer and his student Mrs Andrea Ritrer provided the preliminary information about the different diluents, which is gratefully acknowledged.

The Alexander von Humboldt Stiftung has generously given financial support, which made this work possible.

\section{ZUSAMMENFASSUNG}

\section{BIOLOGIE DER SPERMATOZOEN DER HONIGBIENE (APIS MELLIFERA L.) : \\ 1. WIRKUNG VERSCHIEDENER VERDÜNNUNGSLÖSUNGEN AUF DIE MOTILITÄT UND ÜBERLEBENSDAUER}

Samen von Honigbienen wurde in verschiedenen Verdünnungslösungen für 9 Monate bei einer Temperatur von $14^{\circ} \mathrm{C}$ aufbewahrt. Die Lagerung erfolgte in sterilen Kapillaren von $1 \mathrm{~mm}$ Durchmesser. In regelmässigen Abständen wurde die Beweglichkeit der Spermien geprüft. Ausserdem wurde Sperma frisch verdünnt sowie 60-90 Tage nach der Verdünnung zur Besamung von Königinnen verwendet.

Ein Trispuffer-Verdünner $(\mathrm{pH}=7.19)$ mit einer Konzentration von $\mathrm{K}^{+}$-und $\mathrm{Na}^{+}$-Ionen, wie sie in der Spermatheka von Königinnen gefunden wird, wirkte als reversibler Hemmer der Spermienbeweglichkeit, selbst nach einer Lagerungsdauer von 9 Monaten. Dies stützt unsere frühere Hypothese von einer IonenBasis der Kontrolle von Beweglichkeit und Langlebigkeit der Spermien.

Der Wert anderer Verdünner, die für die Lagerung des Samens anderer Haustiere gebräuchlich sind, wird in Hinblick auf die in vitro Lebensdauer von Bienen-Spermatozoen diskutiert. Spermatozoen leben länger in einem Trispuffer-Verdünner von $\mathrm{pH} 7,19$ als von $\mathrm{pH} 8,4$.

Trispuffer-Verdünner mit Kationen und Varhom-Verdünner II mit Katalase können wahrscheinlich für die Volumsvermehrung von frisch ejakuliertem Samen verwendet werden. Der frisch verdünnte Samen erreichte jedenfalls die Samenblase in der gleichen Anzahl wie der unverdünnte. Diese Methode hat besondere Bedeutung, wenn Besamungen mit einem einzigen Drohnen für genetische Studien nötig sind. Wurden Königinnen jedoch mit Sperma besamt, das 60-90 Tage lang gelagert worden war. dann erreichten weniger als eine halbe Million Spermatozoen die Spermatheka.

Die Entwicklung eines Verdünners für die Langzeitlagerung von Bienensperma erscheint schwieriger als für andere Haustiere, weil in diesem Falle Millionen von Spermatozoen über einen Zeitraum von drei und mehr Jahren voll lebensfähig bleiben müssen.

\section{RÉSUMÉ}

BIOLOGIE DES SPERMATOZOIDES DE LABEILLE ( $A P I S M E L L I C A$ L.)

\section{ACTION DE DIVERS DILUANTS SUR LEUR MOTILITÉ ET LEUR SURVIE}

Du sperme d'abeille a été stocké à $14^{\circ} \mathrm{C}$ dans divers diluants pendant 9 mois dans de fins tubes capillaires stériles d'un mm de diamètre. On évalua la motilité du sperme à intervalles réguliers et insémina des reines avec des échantillons de sperme âgé de 60 à 90 jours et fraichement dilué. Le diluant à tampon Tris 
$(p \mathrm{H}: 7,19)$ a la même concentration en $\mathrm{K}^{+}$et $\mathrm{Na}^{+}$que celle de la spermathèque de la reine et agit comme inhibiteur réversible de la motilité du sperme, même après 9 mois de stockage. Cela confirme notre hypothèse antérieure sur la base ionique du contrôle de la motilité et de la longévité du sperme.

On discute l'importance, pour la survie in vitro des spermatozoìdes d'abeille, de divers autres diluants utilisés pour conserver le sperme d'autres animaux domestiques. Les spermatozoïdes ont survécu plus longtemps dans le diluant à tampon Tris à $p \mathrm{H} 7,19$ qu'à $p \mathrm{H} 8,4$.

Il est possible d'utiliser le diluant tampon Tris avec cations et le diluant Varhom II avec catalase pour augmenter le volume du sperme récemment éjaculé, particulièrement lorsque des études génétiques nécessitent des inséminations par un seul mâle. Pourtant lorsque les reines furent inséminées avec des échantillons de sperme âgé de 60 à 90 jours, moins d'un demi million de spermatozoïdes atteignirent la spermathèque. La mise au point d'un diluant pour le stockage prolongé du sperme d'abeille semble beaucoup plus compliquée que pour les autres animaux domestiques parce qu'il faudrait, dans le premier cas, que des millions de spermatozoïdes restent viables dans la spermathèque pendant 3 ans ou plus.

\section{RÉFÉRENCES}

Camargo C. A. De, 1975. - Biology of the spermatozoon of Apis mellifera, 1. Influence of diluents and $p$ H. J. apic. Res., 14, 113-118.

Gessner B. and Gessner K., 1976. - Inorganic ions in spermathecal fluid and their transport across the spermathecal membrane of the queen bee, Apis mellifera. J. Insect Physiol., 22, 1469-1474.

JAYCOX E. R., 1960. - The effect of drying and various diluents on spermatozoa of the honeybee, Apis mellifera L. J. econ. Ent., 53, 266-269.

LENSKY Y. and SCHINDLER H., 1967. - Motility and reversible inactivation of honeybee spermatozoa in vivo and in vitro. Ann. Abeille, 10, 5-16.

MeLnichenko A. N. and Vavilov Yu. L., 1975. - Long term storage of drone semen by freezing in liquid nitrogen. Proc. 25th. International Congress, Grenoble-France, 311-314.

NELSON L., 1967. - Sperm motility. In Fertilization: Comparative Morphology, Biochemistry and Immunology, ed. C. B. Metz and Montoy A., 1, 27-97 New York : Academic Presse.

Novak A. F., Blum M. S., TABer S. III, and Luiso J. A., 1960. - Separation and determination of seminal plasma and sperm amino acids of the honeybee Apis mellifera. Ann. ent. Soc. Amer., 53, 841-843.

PAUfter S. K., 1974. - Künstliche Besamung und Eitransplantation bei Tier und Mensch., 1, 48-98. Hannover: Verlag M. and $\mathrm{H}$.

Poole H. K. and TABER S. III, 1969. - A method for in vitro storage of honeybee semen. A m. Bee J., 109, 420-421.

Poole H. K. and TABER S. III, 1970. - In vitro preservation of honeybee semen enhanced by storage at 13-15 ${ }^{\circ}$ C. Ann. ent. Soc. Amer., 63, 1673-1674.

RoTHSCHILD Lord, 1948. - The physiology of sea urchin spermatozoa. Lack of movement of semen. $J$. exp. Biol., 25, 344-352.

RUTTNER F., 1975. - The instrumental insemination of the queen bee, 11-38. Bucharest: Apimondia Printing House.

Salisbury G. W. and Graves C. N., 1963. - Substrate free epididymal like bovine spermatozoa. $J$. Reprod. Fertily, 6, 351.

Salisbury G. W. and Lodge J. R., 1962. - Metabolism of spermatozoa. Adv. Enzymol., 24, 35-104.

TABer S. III and Blum M. S., 1960. - Preservation of honeybee semen. Science, N. Y., 131, 1734-1735.

Tosic J. and WALToN A., 1950. - Metabolism os spermatozoa. The formation and elimination of hydrogen peroxide and its effects on motility and survival. Biochem. J., 47, 199-212.

VERMA L. R., 1973. - An ionic basis for a possible mechanism of sperm survival in the spermatheca of the queen honey bee. Apis mellifera L. Comp. Biochem. Physiol., 44 A, 1325-1331. 